\title{
Trough Melatonin Levels Have No Physiological or Clinical Relevance
}

\author{
David J. Kennaway \\ Robinson Research Institute and Adelaide School of Medicine, University of Adelaide, Adelaide, Australia
}

\section{TO THE EDITOR}

A recent study published in this journal compared trough melatonin levels among elderly people with different severities of cognitive deficits [1]. The authors concluded that "that trough melatonin levels in the peripheral blood were decreased in mild cognitive impairment $(\mathrm{MCl})$ but increased with the severity of Alzheimer's disease (AD)" and "that the finding supports the trials indicating that melatonin showed efficacy only in $\mathrm{MCl}$ but not in AD". For this study, the authors chose to collect blood samples between 8 and 12 AM for measuring what they called the "trough level" reasoning that it might be more feasible than peak melatonin or total melatonin secretion for large-scale screening in the elderly people. The melatonin levels in the healthy controls were $92.9 \pm 53.6$ $\mathrm{pg} / \mathrm{ml}$, for amnestic $\mathrm{MCl}, 55.3 \pm 49.7 \mathrm{pg} / \mathrm{ml}$, for mild $\mathrm{AD}$, $71.5 \pm 49.9 \mathrm{pg} / \mathrm{ml}$ and for moderate to severe $\mathrm{AD}, 115.7 \pm$ $60.1 \mathrm{pg} / \mathrm{ml}$.

There are major problems with this study that make the conclusions unsound. First, we know that melatonin production in humans ceases at around $4 \mathrm{AM}$ and thereafter the plasma levels of melatonin decline rapidly to extremely low levels by $8 \mathrm{AM}[2,3]$. Measuring melatonin in a single sample that has been collected between 8 and 12 AM cannot provide any meaningful estimate of the timing of melatonin secretion onset or total melatonin production. This has been clearly articulated in the published recent guidelines for the Journal of Pineal Research [4].

Received: February 9, 2021 / Accepted: February 13, 2021 Address for correspondence: David J. Kennaway Robinson Research Institute and Adelaide School of Medicine, University of Adelaide, Adelaide Health and Medical Science Building, North Terrace, Adelaide, South Australia 5005, Australia E-mail: david.kennaway@adelaide.edu.au ORCID: https://orcid.org/0000-0002-5864-3514
Second, there is extensive evidence showing that in healthy subjects the levels of melatonin between 8 and 12 AM are less than $10 \mathrm{pg} / \mathrm{ml}$ and in Chinese males as low as $3 \mathrm{pg} / \mathrm{ml}$ [5]. Contrast this with the levels of melatonin reported for healthy 66 year olds in the current study of 93 $\mathrm{pg} / \mathrm{ml}$. Studies on melatonin levels in patients with cognitive disturbances using multiple sampling and valid assays that were not referenced in the current paper provide support for very low levels of melatonin in the morning in healthy subjects and the cognitively impaired [6-8] and for the impact of cognitive impairment on melatonin production.

The third and most important issue relates to how the authors assayed their samples and obtained the high morning plasma melatonin results. The authors used a direct melatonin ELISA kit purchased from MyBioSource, San Diego, CA, USA. The catalogue number of the kit was not specified but the detailed description of the procedure would suggest that the kit was manufactured by Cusabio, Wuhan, China (Cat \#-CSB-E08132h). The use of direct (no extraction) ELISA assays to analyse plasma melatonin is known to result in the gross over estimation of the melatonin levels [9]. This is because many of the assay kits available commercially have not been properly validated and are subject to cross reaction from melatonin precursors or metabolites, chemically unrelated substances or interference by plasma proteins. The assay used in the current study has been identified as producing high morning melatonin levels previously in healthy adult humans [9].

In summary, the results in the paper by Lin and colleagues [1] are unsound, due to the study's poor design (single morning sample) and the use of a poorly validated direct ELISA. The suggestion that "trough melatonin levels" have any physiological or clinical relevance needs to

(c) This is an Open-Access article distributed under the terms of the Creative Commons Attribution Non-Commercial License (http://creativecommons.org/licenses/by-nc/4.0) which permits unrestricted non-commercial use, distribution, and reproduction in any medium, provided the original work is properly cited. 
be disregarded.

\section{Conflicts of Interest}

The author declares that the author and the University of Adelaide have previously received payment and reagents from Buhlmann Laboratories as part of a licensing agreement for the supply of the goat anti-melatonin serum known as G280 for use in their RK-MEL2, RK-DSM2 and EK-DSM kits. The University of Adelaide currently licences the G280 antibody to NovoLytiX GmbH for use in their kits.

\section{REFERENCES}

1. Lin $\mathrm{CH}$, Chiu CC, Lane HY. Trough melatonin levels differ between early and late phases of Alzheimer disease. Clin Psychopharmacol Neurosci 2021;19:135-144.

2. Fourtillan JB, Brisson AM, Fourtillan M, Ingrand I, Decourt JP, Girault J. Melatonin secretion occurs at a constant rate in both young and older men and women. Am J Physiol Endocrinol Metab 2001;280:E11-E22.
3. Lewy AJ, Cutler NL, Sack RL. The endogenous melatonin profile as a marker for circadian phase position. J Biol Rhythms 1999; 14:227-236.

4. Lockley SW. Journal of Pineal Research guideline for authors: measuring melatonin in humans. J Pineal Res 2020;69: e12664.

5. Hsing AW, Meyer TE, Niwa S, Quraishi SM, Chu LW. Measuring serum melatonin in epidemiologic studies. Cancer Epidemiol Biomarkers Prev 2010;19:932-937.

6. Uchida K, Okamoto N, Ohara K, Morita Y. Daily rhythm of serum melatonin in patients with dementia of the degenerate type. Brain Res 1996;717:154-159.

7. Mishima K, Tozawa T, Satoh K, Matsumoto Y, Hishikawa Y, Okawa M. Melatonin secretion rhythm disorders in patients with senile dementia of Alzheimer's type with disturbed sleep-waking. Biol Psychiatry 1999;45:417-421.

8. Waller KL, Mortensen EL, Avlund K, Fagerlund B, Lauritzen M, Gammeltoft $\mathrm{S}$, et al. Melatonin and cortisol profiles in late midlife and their association with age-related changes in cognition. Nat Sci Sleep 2016;8:47-53.

9. Kennaway DJ. Measuring melatonin by immunoassay. J Pineal Res 2020;69:e12657. 